\title{
Wpływ nanorurek węglowych (CNTs) na parametry mechaniczne kamieni cementowych w warunkach HPHT
}

\section{Influence of carbon nanotubes (CNTs) on the mechanical parameters of cement stones under HPHT conditions}

\author{
Miłosz Kędzierski, Marcin Rzepka, Marcin Kremieniewski \\ Instytut Nafty i Gazu - Państwowy Instytut Badawczy
}

\begin{abstract}
STRESZCZENIE: Artykuł przedstawia wyniki badań wpływu nanorurek węglowych (CNTs) na parametry mechaniczne kamieni cementowych w warunkach HPHT. W badaniach zastosowano wielościenne nanorurki węglowe (MWCNTs) o średnicy zewnętrznej 10-20 nm i długości 10-30 $\mu \mathrm{m}$. Do zaczynów dodawano 0,1\% nanorurek węglowych. Receptury cementowe opracowane zostały w Laboratorium Zaczynów Uszczelniających Instytutu Nafty i Gazu - Państwowego Instytutu Badawczego. Badania przeprowadzono w warunkach podwyższonego ciśnienia i temperatury w zakresie temperatur $60-130^{\circ} \mathrm{C}$ i zakresie ciśnien $25-80 \mathrm{MPa}$. W przypadku temperatury $60^{\circ} \mathrm{C}$ jako spoiwo wiążące zastosowano cement portlandzki CEM I 42,5R oraz cement wiertniczy G. Zaczyny dla temperatur od $80^{\circ} \mathrm{C}$ do $130^{\circ} \mathrm{C}$ sporządzono na osnowie cementu wiertniczego G. Przy opracowywaniu receptur kierowano się wymaganiami, jakie powinien spełniać zaczyn cementowy użyty do cementowania rur okładzinowych w warunkach występowania bardzo wysokich temperatur oraz ciśnień złożowych. Zaczyny posiadały gęstość od około $1840 \mathrm{~kg} / \mathrm{m}^{3}$ (zaczyny dla temperatury $60^{\circ} \mathrm{C}$ ) do około $2250 \mathrm{~kg} / \mathrm{m}^{3}$ (zaczyny z dodatkiem hematytu). Badania wytrzymałości na ściskanie i przyczepności do rur prowadzono po 2, 7, 14 i 28 dniach. Opracowano receptury o bardzo dobrych parametrach technologicznych, które po utwardzaniu (po okresie 28 dni hydratacji) posiadały bardzo wysokie wartości wytrzymałości na ściskanie, osiągające nawet do $44 \mathrm{MPa}$. Uzyskano również wysokie wartości przyczepności kamienia cementowego do rur, dochodzące do około $8 \mathrm{MPa}$ po 28 dniach hydratacji, oraz wytrzymałości na zginanie, wynoszące około 11 MPa. Przeprowadzone badania ujawniają pozytywny wpływ dodatku nanorurek węglowych na wytrzymałość kamieni cementowych z ich dodatkiem. Zmodyfikowane w ten sposób kamienie charakteryzują się wysokimi wartościami wytrzymałości na ściskanie oraz wysokimi przyczepnościami do rur stalowych. Konieczne są jednak dalsze badania w kierunku określenia wpływu nanorurek węglowych na mikrostrukturę stwardniałych zaczynów cementowych. Niezbędne jest również kontynuowanie badań nad określeniem optymalnych ilości tych środków oraz doborem najbardziej kompatybilnych dodatków do zaczynów cementowych działających w sposób optymalny w połączeniu z nanocząsteczkami.
\end{abstract}

Słowa kluczowe: nanorurki węglowe (CNTs), kamień cementowy, wytrzymałość na ściskanie, zaczyn cementowy.

ABSTRACT: The article presents the results of testing the influence of carbon nanotubes on the mechanical parameters of cement stones under HPHT conditions. Multi-walled carbon nanotubes (MWCNTs) with an external diameter of 10-20 nm and a length of 10-30 $\mu \mathrm{m}$ were used for testing. $0.1 \%$ of carbon nanotubes was added to the cement slurry. Laboratory tests of cement slurries were carried out at Oil and Gas Institute - National Research Institute. The tests were carried out under conditions of increased pressure and temperature in the temperature range of $60-130^{\circ} \mathrm{C}$ and the pressure range of 25-80 MPa. CEM I 42.5R Portland cement and Class G drilling cement were used to make the slurries at temperature of $60^{\circ} \mathrm{C}$. Cement slurries for temperatures from $80^{\circ} \mathrm{C}$ to $130^{\circ} \mathrm{C}$ were prepared on the basis of class $\mathrm{G}$ drilling cement. The recipes were developed on the basis of the requirements to be met by cement slurry for the cementing of casing under conditions of very high temperatures and reservoir pressures. The densities of tested slurries ranged from $1,840 \mathrm{~kg} / \mathrm{m}^{3}$ (slurries at a temperature of $60^{\circ} \mathrm{C}$ ) to $2.250 \mathrm{~kg} / \mathrm{m}^{3}$ (slurries with the addition of hematite).Compressive strength tests and adhesion measurements were carried out after 2, 7, 14 and 28 days. Cement slurry recipes with very good technological parameters were developed, which after curing (after 28 days of hydration) showed very high values of compressive strength, reaching up to $44 \mathrm{MPa}$. Cements were characterized by high values of adhesion to pipes reaching up $8 \mathrm{MPa}$ after 28 days and flexural strength of about $11 \mathrm{MPa}$. The test results show that the addition of carbon nanotubes has a positive effect on the mechanical strength of cement stones with their addition. The stones modified in this way are characterized by high compressive strength and high adhesion to steel pipes. Further research is needed to determine the influence of carbon nanotubes on the microstructure of hardened cement slurries. It is also necessary to conduct further research on the determination of the optimal amounts of these agents and the selection of the most compatible additives for cement slurries that work optimally in combination with nanoparticles.

Key words: carbon nanotubes (CNTs), cement stone, compressive strength, cement slurry.

Autor do korespondencji: M. Kędzierski, e-mail: milosz.kedzierski@inig.pl

Artykuł nadesłano do Redakcji: 19.11.2020 r. Zatwierdzono do druku: 02.02.2021 r. 


\section{Wprowadzenie}

Wydobycie ropy naftowej i gazu ziemnego oraz ich eksploracja mają ogromny wpływ na strukturę gospodarczą świata. Ponieważ w ciągu ostatnich dziesięcioleci łatwo dostępne zasoby ropy naftowej zostały odkryte i zagospodarowane, to aby sprostać rosnącemu zapotrzebowaniu na energię, niezbędne są dodatkowe poszukiwania złóż występujących w trudnych warunkach geologicznych, a także niekonwencjonalnych zasobów węglowodorów. W ciągu ostatnich dwóch dziesięcioleci wielkość rocznego zużycia ropy naftowej przekroczyła wielkość jej nowo odkrytych zasobów, dlatego z czasem perspektywa ostatecznego spadku wydobycia ropy naftowej staje się realistycznym scenariuszem. Jednak dokładna ilość nieodkrytych zasobów ropy nie jest dobrze znana. Poszukiwania nowych złóż ropy i gazu stają się coraz trudniejsze ze względu na coraz większe głębokości ich zalegania, a co się z tym łączy - coraz wyższe temperatury i ciśnienia. W głębokich otworach wysokie ciśnienie i wysoka temperatura oraz operacje po cementowaniu powodują duże naprężenia na kamień cementowy, co może wpływać na niezawodność uszczelnienia rur okładzinowych. Konieczne jest prowadzenie systematycznych badań istniejących technik cementowania i opracowywanie nowych technologii w celu uniknięcia problemów związanych ze zdrowiem, bezpieczeństwem i środowiskiem (HSE). Projektowany zaczyn cementowy musi posiadać właściwości gwarantujące stabilność i długotrwałą integralność płaszcza cementowego w warunkach wysokiego ciśnienia i temperatury (HPHT).

Cementowanie stanowi jeden z kluczowych procesów wykonywanych podczas wiercenia otworu wiertniczego i ma znaczący wpływ na żywotność odwiertu, lecz zależy od obszaru wiercenia i napotkanych interwałów skalnych. Celem cementowania jest uzyskanie jak najlepszego związania rur okładzinowych z formacją skalną i osiągnięcie izolacji strefowej w otworze wiertniczym. Oprócz tego płaszcz cementowy chroni również rury okładzinowe przed korozją oraz obciążeniami podczas głębokich wierceń. W trakcie operacji cementowania zaczyn, składający się głównie z wody, cementu i chemikaliów kontrolujących parametry zaczynu cementowego, jest wtłaczany do otworu, umieszczany w cementowanym interwale $\mathrm{w}$ przestrzeni pierścieniowej między kolumną rur okładzinowych a formacją geologiczną otaczającą odwiert i pozostawiany do związania. Głównym wyzwaniem cementowania jest osiągnięcie pełnej izolacji strefowej. Oznacza to, że należy uzyskać uszczelnienie między cementem a rurami okładzinowymi, jak również między cementem a formacją w cementowanym interwale. Właściwości wiążące mogą zostać zakłócone przez skurcz cementu i wahania ciśnienia i temperatury. Odwierty są narażone na duże zmiany temperatury w formacjach HPHT, a te zmiany wpływają niekorzystnie zarówno na formację, jak i na rury okładzinowe, powodując rozszerzanie się i kurczenie. $Z$ powodu tych rozszerzeń i skurczów rur okładzinowych oraz formacji plastycznych, takich jak sól, następują pęknięcia utworzonego kamienia cementowego. W razie nieuzyskania pełnego uszczelnienia rur okładzinowych odwiert nigdy nie osiągnie pełnego potencjału eksploatacji ropy naftowej lub gazu ziemnego.

Zaczyn cementowy opracowuje się tak, aby zapewnić nisko przepuszczalną matrycę, a tym samym izolować odwiert podczas wiercenia, eksploatacji, aż do skończenia wydobywania medium złożowego. Niestety cel ten nie zawsze się osiąga ze względu na kilka czynników i warunki panujące w otworze wiertniczym. Skamieniały zaczyn cementowy, stanowiący płaszcz cementowy, może ulec uszkodzeniu podczas użytkowania odwiertu i tym samym spowodować utratę integralności odwiertu. Niewłaściwe cementowanie strefowe może prowadzić do niepotrzebnej utraty ciśnienia w złożu, ucieczek węglowodorów, a w najgorszym przypadku do utraty odwiertu z powodu uszkodzenia (np. zgniecenia, rozszczelnienia) rur okładzinowych, wpływając w ten sposób na rentowność projektu. Dodatkowo węglowodory płynące za rurami okładzinowymi mogą również oddziaływać na warstwy wodonośne, powodując katastrofy ekologiczne.

Właściwa receptura zaczynu cementowego do cementowania otworów wiertniczych zależy od wielu czynników, w tym geometrii odwiertu, osprzętu rur okładzinowych, integralności formacji, właściwości płuczki wiertniczej, cieczy przemywających i buforowych oraz warunków mieszania. W ciągu ostatnich kilkudziesięciu lat właściwości zaczynów cementowych zostały ulepszone poprzez dodatek wielu nowych domieszek chemicznych, takich jak opóźniacze wiązania, modyfikatory lepkości, przyspieszacze wiązania, domieszki zwiększające wytrzymałość itp. Rodzaj i dawkowanie dodatków chemicznych stosowanych w zaczynach cementowych decydują o wczesnej wytrzymałości i innych właściwościach kamieni cementowych. Wykorzystane dodatki i domieszki chemiczne silnie wpływają na właściwości chemiczne i fizyczne zaczynów i kamieni cementowych. Interakcje cementów wiertniczych z różnymi rodzajami domieszek i związana z tym kompatybilność domieszek i cementu w wysokich temperaturach są nadal w dużym stopniu niezbadane.

Jak w każdej dziedzinie nauki, także w wiertnictwie dąży się do tworzenia nowych, ulepszonych i przyjaznych środowisku produktów. Dlatego też intensywne poszukiwanie alternatywnych materiałów do cementowania otworów wiertniczych trwa na całym świecie. Wymagane jest, aby z tych niekonwencjonalnych materiałów powstał kamień cementowy, który jest mocniejszy, trwalszy czy też bardziej ekologiczny (Patil i Deshpande, 2012). 
Nanonauka i nanotechnologia znalazły zastosowanie w przemyśle naftowym i są wykorzystywane w wielu obszarach, m.in. w nanotechnologii płuczek wiertniczych i zaczynów cementowych. W ciągu ostatnich kilku lat wielu naukowców przeprowadziło badania związane z poprawą i zrozumieniem zachowania zaczynów cementowych z dodatkiem nanomateriałów. Przebadano kilka rodzajów nanomateriałów, takich jak nanokrzemionka, nanoił, nanotlenki żelaza, glinu, cynku i tytanu (Li H. et al., 2004; Li Z. et al., 2006; Ershadi i Ebadi, 2011; Nazari i Riahi, 2011; De La Roij et al., 2012; Dębińska, 2014, 2015, 2016; Dębińska et al., 2016; Rahman et al., 2016a, 2016b). Włączenie materiałów nanometrycznych do struktury hydratu krzemianu wapnia (C-S-H) skutkuje mocniejszą i bardziej plastyczną matrycą cementową, która może zapobiec propagacji pęknięć w stwardniałym zaczynie cementowym (De La Roij et al., 2012). Nanorurki węglowe (CNTs) obecnie cieszą się bardzo dużym zainteresowaniem jako nanomateriały ze względu na swoje unikatowe i cenne właściwości, takie jak wytrzymałość na rozciąganie, moduł sprężystości, elektryczne i termiczne przewodnictwo (Dresselhaus et al., 1996). Wiele ośrodków naukowych podejmuje tematykę badawczą związaną z nanomateriałami węglowymi ze względu na ich obecne i liczne perspektywiczne zastosowania (Li G.Y. et al., 2007; Luo et al., 2009; Kuilla et al., 2010; Huang et al., 2012, Nasibulin et al., 2013, Ghajari et al., 2014).

$\mathrm{W}$ trakcie realizacji zadania przeprowadzono badania laboratoryjne mające na celu określenie wpływu nanorurek węglowych na parametry mechaniczne kamieni cementowych w warunkach HPHT.

\section{Nanotechnologia i nanorurki węglowe}

Nanotechnologia to dziedzina nauki zajmująca się m.in. badaniem, projektowaniem i wytwarzaniem komponentów o bardzo małych rozmiarach. Komponenty te mają wielkość ziaren rzędu kilkudziesięciu nanometrów, co pozwala na uzyskanie z nich produktów o szczególnych właściwościach technologicznych. Możliwości zastosowań tzw. nanomateriałów, tj. materiałów o wymiarze cząstek, wymiarze porów lub grubości filmu w przedziale od $1 \mathrm{~nm}$ do $100 \mathrm{~nm}$, są niezwykle duże, a intensywny rozwój nauki w tej dziedzinie sprawia, że pierwsze dekady XXI wieku określane są początkiem ery nanotechnologii.

Rozwój technologii doskonalenia kompozycji cementowych na przestrzeni ostatnich lat odbywał się głównie na drodze wykorzystywania coraz drobniejszych materiałów (Patil i Deshpande, 2012; Horszczaruk et al., 2013). W kolejnych etapach rozwoju i wytwarzania cementu następowało ograniczenie wielkości ziaren stosowanych składników, np. średnica ziarna zmielonego piasku wynosi około 0,04-0,05 mm (tj. około 40 000-50 000 nm), pyłu krzemionkowego - 150-200 nm, natomiast nanokrzemionki, nanoglinu czy nanorurek węglowych (najmniejszy wymiar) - około 10-20 nm. Zastosowanie zatem nanokrzemionki, nanoglinu czy nanorurek węglowych w składzie zaczynu cementowego jest znaczącym krokiem w rozwoju technologicznym tej gałęzi przemysłu (Kuilla et al., 2010; De La Roij et al., 2012; Huang et al., 2012; Nasibulin et al., 2013). Nanocząsteczki (zarówno n- $\mathrm{SiO}_{2}$, jak i n- $\mathrm{Al}_{2} \mathrm{O}_{3}$ czy nanorurki węglowe) wypełniają puste przestrzenie między ziarnami cementu, w wyniku czego następuje zamknięcie kanałów porowych w matrycy cementowej (Li H. et al., 2004; Li Z. et al., 2006; Nazari i Riahi, 2011). Ponadto odpowiednio zdyspergowane nanocząsteczki powodują przyspieszenie hydratacji zaczynu cementowego i sprzyjają tworzeniu się niewielkich kryształów oraz małych jednorodnych skupisk fazy C-S-H - głównego budulca matrycy cementowej - odpowiadającej za jeden z najważniejszych parametrów zaczynu, jakim jest wytrzymałość mechaniczna. Dodatkowo nanocząsteczki uczestniczą w reakcjach pucolanowych lub je przyspieszają, w wyniku czego w twardniejącym cemencie „zużywaniu” ulega część nietrwałego chemicznie portlandytu $\mathrm{Ca}(\mathrm{OH})_{2}$, a tworzy się „,dodatkowy” żel fazy C-S-H, wzmacniający szkielet matrycy cementowej (Al-Saud et al., 2011; Nazari i Riahi, 2011). Za kolejną cechę pozytywną nanocząsteczek należy uznać poprawianie struktury kontaktu na styku ziaren cementowych, co skutkuje mocniejszym związaniem oraz ograniczeniem ewentualnych pęknięć.

Nanorurki węglowe zostały odkryte przez Sumio Iijimę w 1991 roku za pomocą mikroskopu elektronowego o wysokiej rozdzielczości (HREM), co spowodowało rozpoczęcie intensywnych badań eksperymentalnych i teoretycznych dotyczących właśnie nanorurek węglowych (Pandey i Dahiya, 2016).

Nanorurki węglowe są jedną z odmian alotropowych węgla. Zbudowane są ze zwiniętych cylindrycznie warstw grafenowych. Nanorurki mają postać czarnego proszku. Są praktycznie nierozpuszczalne w wodzie $\mathrm{i} w$ rozpuszczalnikach organicznych. Nanorurki węglowe różnią się między sobą długością, średnicą, a także kątem skrętności. Z powodu oddziaływania sił van der Waalsa między ścianami nanorurek - ulegają one agregacji, konieczne jest więc rozdzielenie wiązek nanorurek na pojedyncze nanorurki. Dokonuje się tego, poddając zawiesinę nanorurek działaniu ultradźwięków. Nanorurki węglowe mają bardzo dużą wytrzymałość teoretyczną - około 100 razy większą niż w przypadku stali przy 6-krotnie niższej wadze. Moduł Younga i wytrzymałość na rozciąganie wynoszą odpowiednio 1 TPa i 200 GPa. 


\section{Wpływ nanorurek węglowych na właściwości zaczynów cementowych}

Nanorurki węglowe (CNTs) mają doskonałe właściwości mechaniczne i dlatego w połączeniu ze zwykłym cementem portlandzkim mogą tworzyć nanokompozyty twardsze niż tradycyjne materiały wzmacniające (np. włókna szklane lub włókna węglowe) (Haddad i de Morais, 2014). Dodanie CNTs prowadzi do wzrostu ilości kryształów hydratów powstających w zaczynie cementowym i zmiany ich struktury morfologicznej (Al-Saud et al., 2011). Dotychczasowe badania wykazały, że dodatek nanorurek węglowych może zwiększyć wytrzymałość kamienia cementowego (Campillo et al., 2004; Li X. et al., 2019). Stwierdzono, że mała ilość skutecznie rozproszonych CNTs może znacznie zwiększyć wytrzymałość na zginanie. Dodatek krótkich, wielościennych CNTs w ilości $0,08 \%$ spowodował wzrost wytrzymałości na zginanie o $35 \%$ oraz zwiększenie się modułu Younga (KostaGdoutos et al., 2010, Wang et al., 2013). Jeszcze lepsze wyniki uzyskano w przypadku wytrzymałości na ściskanie. Dodatek CNTs w ilości 1,0\% w stosunku do masy suchego cementu doprowadził do wzrostu wytrzymałości na ściskanie do wartości 51,8 MPa po 28 dniach hydratacji (Li Z. et al., 2006; Chaipanich et al., 2010; Al-Saud et al., 2011). Li G.Y. $\mathrm{i}$ in. $(2005,2007)$ uzyskali 25 -procentowy wzrost wytrzymałości na zginanie i 19-procentowy wzrost wytrzymałości na ściskanie. Cwirzen i in. (2009) po zastosowaniu MWCNTs stanowiących $0,045-0,15 \%$ masy suchego cementu (bwoc) otrzymali kamienie cementowe o wytrzymałości na ściskanie wyższej o $50 \%$ w stosunku do próbki bazowej. Poprawę właściwości mechanicznych zaczynu cementowego osiągnięto także po dodaniu 0,1\% CNTs (El-Gamal et al., 2017; De Paula et al., 2018). De Paula i in. (2014) podali, że średni 15-procentowy wzrost wytrzymałości na rozciąganie uzyskano dla próbek po 48 godzinach oraz 7 dniach hydratacji po dodatku $0,1 \%$ CNTs. W innych badaniach stwierdzono, że dodatek nanorurek do kompozytów cementowych spowodował spadek wytrzymałości na ściskanie (Collins et al., 2012). Modyfikacja zaczynu cementowego za pomocą dodatku CNTs w ilości $0,5 \%$ (bwoc) spowodowała spadek wytrzymałości na ściskanie o około 80\% (Musso et al., 2009). Zróżnicowany wpływ dodatków CNTs na właściwości mechaniczne materiałów cementowych można prawdopodobnie wyjaśnić różnymi wyborami rodzaju i ilości CNTs oraz metodami rozpraszania nanorurek. Wpływ nanorurek węglowych na kompozyty cementowe jest ograniczony przez ich wysoką cenę. Nawet przy niewielkich dodawanych ilościach obecne ceny nanorurek węglowych są zbyt wysokie, żeby produkcja ważnych struktur kompozytowych była opłacalna. Materiał kompozytowy z dodatkiem CNTs może być zastosowany w przypadkach, w których wymaganie uzyskania ultrawysokich twardości i wytrzymałości rekompensuje cenę nanorurek i potencjalne trudności. Nanotechnologia oferuje możliwości precyzyjnego konstruowania cementu do specyficznych zastosowań, redukcję późniejszych kosztów i wzrost wydajności.

\section{Badania laboratoryjne}

Testy i badania laboratoryjne mające na celu analizę wpływu nanorurek węglowych na parametry mechaniczne kamieni cementowych w warunkach HPHT były wykonywane w Zakładzie Technologii Wiercenia INiG - PIB Oddział Krosno w Laboratorium Zaczynów Uszczelniających zgodnie z normami API Spec 10: Specification for Materials and Testing for Well Cements, Przemyst naftowy i gazowniczy - Cementy i materiaty do cementowania otworów - Część 1: Specyfikacja (PN-EN ISO 10426-1:2009) oraz Przemyst naftowy $i$ gazowniczy - Cementy i materiały do cementowania otworów wiertniczych - Część 2: Badania cementów wiertniczych (PN-EN ISO 10426-2:2003).

Dla każdego zaczynu cementowego wykonano pomiar wytrzymałości na zginanie i ściskanie po 2, 7, 14 i 28 dniach, a także pomiar przyczepności do rur stalowych.

W badanych zaczynach cementowych jako spoiwo wiążące zastosowano cement portlandzki CEM I 42,5R oraz cement wiertniczy G. W badaniach wykorzystano wielościenne nanorurki węglowe (MWCNTs) o średnicy zewnętrznej 10-20 nm i długości 10-30 $\mu \mathrm{m}$. Czystość nanorurek węglowych była wyższa niż 95\%. Zaczyny cementowe sporządzano na wodzie wodociągowej. Zawierały one: upłynniacz, dodatek odpieniający, dodatek antyfiltracyjny, dodatek opóźniający wiązanie, $\mathrm{KCl}, \mathrm{NaCl}$, mikrocement, mikrokrzemionkę, hematyt oraz nanorurki węglowe. Ilość nanorurek węglowych i pozostałych składników (poza $\mathrm{KCl}$ i $\mathrm{NaCl}$ - dodawanymi w stosunku do wody) dodawano w stosunku do cementu. Stosunek w/c wynosił 0,48-0,57. Nanorurki węglowe dodawano do wody i dyspergowano przy użyciu sonifikatora Sonics VC 505 (amplituda: 70\%, czas: 3 minuty). Badania przeprowadzono w temperaturach $60-130^{\circ} \mathrm{C}$. Wykonano próbki porównawcze niezawierające dodatku nanorurek węglowych.

\section{Wyniki badań}

Poniżej przedstawiono wyniki badań bazowych zaczynów cementowych oraz optymalnych zaczynów cementowych z dodatkiem nanorurek węglowych dla temperatur w zakresie od $60^{\circ} \mathrm{C}$ do $130^{\circ} \mathrm{C}$. 


\section{Zaczyny cementowe dla temperatury $60^{\circ} \mathrm{C}$}

$\mathrm{W}$ tabeli 1 przedstawiono skład i parametry zaczynu bazowego, bez dodatku nanorurek węglowych. Gęstość zaczynu wyniosła $1,84 \mathrm{~g} / \mathrm{cm}^{3}$. Zaczyn charakteryzował się odpowiednią reologią i zerowym odstojem wody. Uzyskał on konsystencję $30 \mathrm{Bc}$ po czasie 3 godz. $28 \mathrm{~min}$, a $100 \mathrm{Bc}$ po 4 godz. 7 min. Filtracja zaczynu miała wartość $160 \mathrm{~cm}^{3}$. Na rysunku 1 zaprezentowano wykres wytrzymałości na ściskanie, zginanie i przyczepność do rur kamienia cementowego. Wytrzymałość kamienia cementowego na ściskanie po 28 dniach była równa 42,5 $\mathrm{MPa}$, wytrzymałość kamienia cementowego na zginanie miała wartość 10,5 MPa, z kolei przyczepność do rur wynosiła 7,0 MPa.

$\mathrm{W}$ tabeli 2 przedstawiono skład i parametry zaczynu nr $1 \mathrm{a}$. Zaczyn zawierający 0,1\% nanorurek węglowych (MWCNTs), charakteryzował się dobrymi parametrami reologicznymi. W porównaniu z zaczynem bazowym zwiększono o 0,05\% ilość środka upłynniającego. Zaczyn ten uzyskał konsystencję 30 Bc po czasie 3 godz. 8 min, a $100 \mathrm{Bc}$ po 4 godz. 7 min. Filtracja wynosiła $122 \mathrm{~cm}^{3} / 30 \mathrm{~min}$ i była niższa o $38 \mathrm{~cm}^{3}$ w porównaniu z zaczynem bazowym. Na rysunku 2 zaprezentowano wykres wytrzymałości na ściskanie, zginanie i przyczepność do rur kamienia cementowego. Można stwierdzić, że wytrzymałość na ściskanie wzrasta wraz z upływem czasu. Po 2 dniach wytrzymałość kamienia cementowego wynosiła około 28,7 MPa, a po 28 dniach - aż 44,3 MPa. Wytrzymałość na zginanie po 28 dniach osiągnęła wartość 10,8 MPa, z kolei przyczepność do rur stalowych była równa 7,7 $\mathrm{MPa}$.

\section{Zaczyny cementowe dla temperatury $80^{\circ} \mathrm{C}$}

W tabeli 3 przedstawiono skład i parametry zaczynu bazowego nr 2, bez dodatku nanorurek węglowych. Gęstość zaczynu wyniosła $1,90 \mathrm{~g} / \mathrm{cm}^{3}$. Zaczyn charakteryzował się odpowiednią reologią i zerowym odstojem wody. Uzyskał on konsystencję $30 \mathrm{Bc}$ po czasie 4 godz. $44 \mathrm{~min}$, a $100 \mathrm{Bc}$ po 5 godz. $27 \mathrm{~min}$. Filtracja zaczynu miała wartość $36 \mathrm{~cm}^{3}$. Rozlewność zaczynu wyniosła $240 \mathrm{~mm}$. Na rysunku 3 zaprezentowano wykres wytrzymałości na ściskanie, zginanie i przyczepność do rur kamienia cementowego. Wytrzymałość kamienia cementowego

Tabela 1. Bazowy zaczyn cementowy nr 1

Table 1. Base cement slurry 1

\begin{tabular}{|c|c|c|c|c|}
\hline \multicolumn{2}{|l|}{ Skład zaczynu 1} & \multicolumn{3}{|c|}{ Parametry zaczynu } \\
\hline Woda & $\mathrm{w} / \mathrm{c}=0,48$ & \multicolumn{2}{|l|}{ Gęstość [g/cm³] } & 1,84 \\
\hline Dodatek upłynniający & $0,25 \%$ & \multicolumn{2}{|c|}{ Rozlewność [mm] } & 270 \\
\hline Dodatek antyfiltracyjny & $0,3 \%$ & \multicolumn{2}{|l|}{ Odstój wody [\%] } & 0,0 \\
\hline Dodatek odpieniający & $0,5 \%$ & \multicolumn{2}{|c|}{ Lepkość plastyczna $[\mathrm{mPa} \cdot \mathrm{s}]$} & 205,5 \\
\hline $\mathrm{KCl}$ (bwow) & $3,0 \%$ & \multicolumn{2}{|c|}{ Granica płynięcia YP $[\mathrm{Pa}]$} & 19,0 \\
\hline Dodatek opóźniający wiązanie & $0,3 \%$ & \multirow{2}{*}{$\begin{array}{l}\text { Czas gęstnienia } \\
\left(60^{\circ} \mathrm{C}, 25 \mathrm{MPa}\right)\end{array}$} & $30 \mathrm{Bc}[\mathrm{h}: \mathrm{min}]$ & $3: 28$ \\
\hline \multirow[t]{2}{*}{ CEM I 42,5R } & $100,0 \%$ & & $100 \mathrm{Bc}[\mathrm{h}: \mathrm{min}]$ & 4:07 \\
\hline & & \multicolumn{2}{|c|}{ Filtracja $[\mathrm{ml} / 30 \mathrm{~min}]$} & 160 \\
\hline \multicolumn{5}{|c|}{ Parametry mechaniczne $\left(60^{\circ} \mathrm{C}\right)$} \\
\hline & 2 dni & $7 \mathrm{dni}$ & 14 dni & $28 \mathrm{dni}$ \\
\hline Wytrzymałość na zginanie [MPa] & 8,8 & 9,0 & 9,5 & 10,5 \\
\hline Wytrzymałość na ściskanie [MPa] & 25,4 & 30,6 & 37,3 & 42,5 \\
\hline Przyczepność do rur [MPa] & 5,1 & 5,9 & 6,3 & 7,0 \\
\hline
\end{tabular}

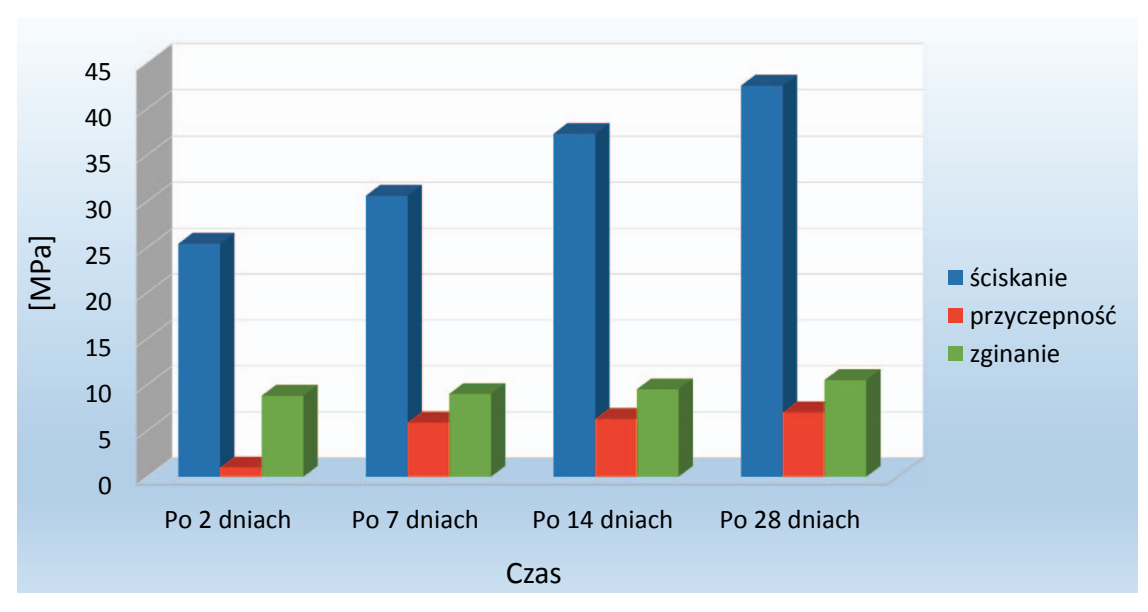

Rys . 1. Wytrzymałość mechaniczna bazowego kamienia cementowego nr 1 Fig. 1. Mechanical strength of the base cement stone 1 
Tabela 2. Zaczyn cementowy nr 1a

Table 2. Cement slurry 1a

\begin{tabular}{|c|c|c|c|c|}
\hline \multicolumn{2}{|c|}{ Sklad zaczynu 1a } & \multicolumn{3}{|c|}{ Parametry zaczynu } \\
\hline Woda & $\mathrm{w} / \mathrm{c}=0,48$ & \multicolumn{2}{|l|}{ Gęstość $\left[\mathrm{g} / \mathrm{cm}^{3}\right]$} & 1,84 \\
\hline Dodatek upłynniający & $0,3 \%$ & \multicolumn{2}{|l|}{ Rozlewność [mm] } & 250 \\
\hline Dodatek antyfiltracyjny & $0,3 \%$ & \multicolumn{2}{|l|}{ Odstój wody [\%] } & 0,0 \\
\hline Dodatek odpieniający & $0,5 \%$ & \multicolumn{2}{|c|}{ Lepkość plastyczna $[\mathrm{mPa} \cdot \mathrm{s}]$} & 204,0 \\
\hline $\mathrm{KCl}$ (bwow) & $3,0 \%$ & \multicolumn{2}{|c|}{ Granica płynięcia YP [Pa] } & 13,0 \\
\hline Dodatek opóźniający wiązanie & $0,3 \%$ & \multirow{2}{*}{$\begin{array}{l}\text { Czas gęstnienia } \\
\left(60^{\circ} \mathrm{C}, 25 \mathrm{MPa}\right)\end{array}$} & $30 \mathrm{Bc}$ [h:min] & 3:08 \\
\hline MWCTN & $0,1 \%$ & & $100 \mathrm{Bc}[\mathrm{h}: \mathrm{min}]$ & 4:07 \\
\hline CEM I 42,5R & $100,0 \%$ & \multicolumn{2}{|c|}{ Filtracja $[\mathrm{ml} / 30 \mathrm{~min}]$} & 122 \\
\hline \multicolumn{5}{|c|}{ Parametry mechaniczne $\left(60^{\circ} \mathrm{C}\right)$} \\
\hline & 2 dni & 7 dni & 14 dni & $28 \mathrm{dni}$ \\
\hline Wytrzymałość na zginanie [MPa] & 9,4 & 9,6 & 9,9 & 10,8 \\
\hline Wytrzymałość na ściskanie [MPa] & 28,7 & 30,9 & 38,1 & 44,3 \\
\hline Przyczepność do rur [MPa] & 5,2 & 6,1 & 6,6 & 7,7 \\
\hline
\end{tabular}

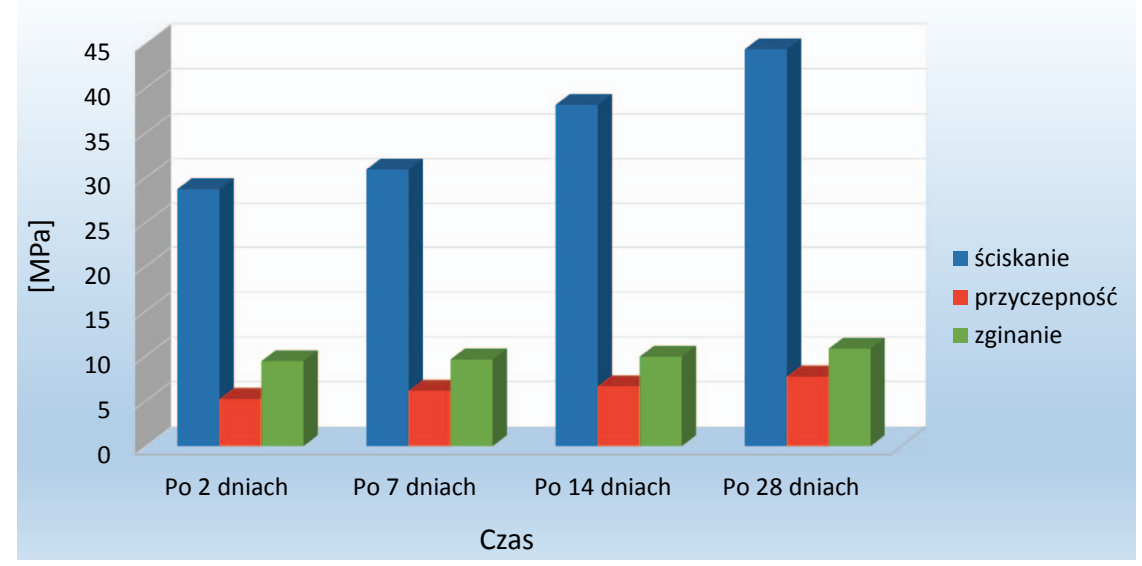

Rys. 2. Wytrzymałość mechaniczna kamienia cementowego $\mathrm{nr} 1 \mathrm{a}$

Fig. 2. Mechanical strength of sample 1a

Tabela 3. Bazowy zaczyn cementowy nr 2

Table 3. Base cement slurry 2

\begin{tabular}{|c|c|c|c|c|}
\hline \multicolumn{2}{|l|}{ Sklad zaczynu 2} & \multicolumn{3}{|c|}{ Parametry zaczynu } \\
\hline Woda & $\mathrm{w} / \mathrm{c}=0,50$ & \multicolumn{2}{|l|}{ Gęstość $\left[\mathrm{g} / \mathrm{cm}^{3}\right]$} & 1,90 \\
\hline Dodatek upłynniający & $0,25 \%$ & \multicolumn{2}{|c|}{ Rozlewność [mm] } & 240 \\
\hline Dodatek antyfiltracyjny 1 & $0,9 \%$ & \multicolumn{2}{|l|}{ Odstój wody [\%] } & 0,0 \\
\hline Dodatek antyfiltracyjny 2 & $0,9 \%$ & \multicolumn{2}{|c|}{ Lepkość plastyczna $[\mathrm{mPa} \cdot \mathrm{s}]$} & 300,0 \\
\hline Dodatek odpieniający & $0,5 \%$ & \multicolumn{2}{|c|}{ Granica płynięcia YP $[\mathrm{Pa}]$} & 10,1 \\
\hline $\mathrm{NaCl}$ (bwow) & $10,0 \%$ & \multirow{2}{*}{$\begin{array}{l}\text { Czas gęstnienia } \\
\left(80^{\circ} \mathrm{C}, 40 \mathrm{MPa}\right)\end{array}$} & $30 \mathrm{Bc}[\mathrm{h}: \min ]$ & $4: 44$ \\
\hline Mikrocement & $5,0 \%$ & & $100 \mathrm{Bc}[\mathrm{h}: \mathrm{min}]$ & $5: 27$ \\
\hline Cement G & $100,0 \%$ & \multicolumn{2}{|c|}{ Filtracja $[\mathrm{ml} / 30 \mathrm{~min}]$} & 36 \\
\hline \multicolumn{5}{|c|}{ Parametry mechaniczne $\left(80^{\circ} \mathrm{C}\right)$} \\
\hline & 2 dni & 7 dni & 14 dni & $28 \mathrm{dni}$ \\
\hline Wytrzymałość na zginanie [MPa] & 8,8 & 9,1 & 9,3 & 9,7 \\
\hline Wytrzymałość na ściskanie [MPa] & 30,1 & 31,1 & 33,7 & 38,1 \\
\hline Przyczepność do rur [MPa] & 5,0 & 5,4 & 5,8 & 6,3 \\
\hline
\end{tabular}




\section{NAFTA-GAZ}

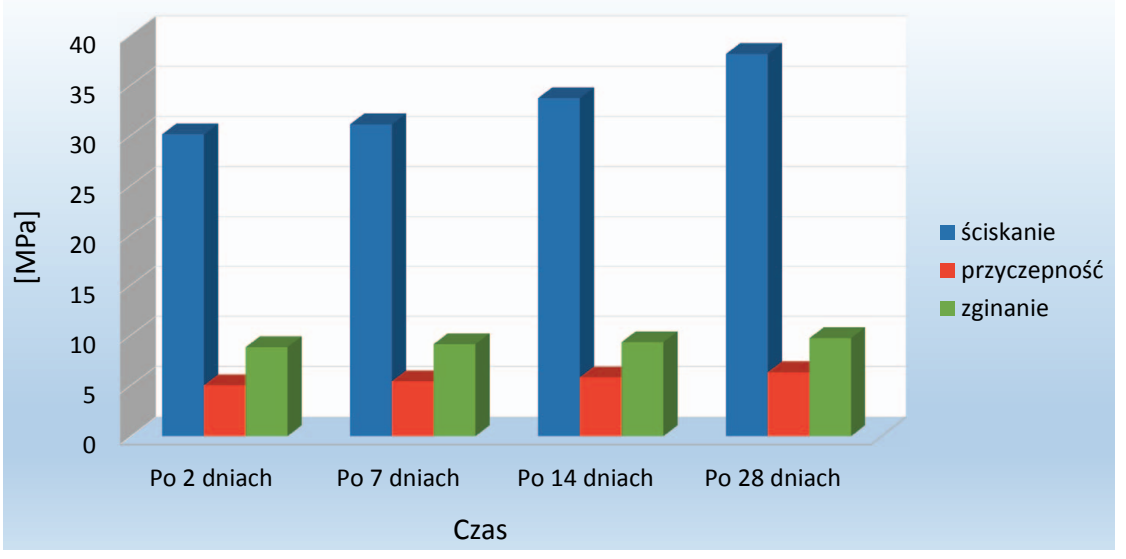

Rys. 3. Wytrzymałość mechaniczna kamienia cementowego $\mathrm{nr} 2$

Fig. 3. Mechanical strength of sample 2

na ściskanie po 28 dniach była równa $38,1 \mathrm{MPa}$, wytrzymałość na zginanie miała wartość 9,7 MPa, a przyczepność do rur wynosiła 6,3 $\mathrm{MPa}$.

W tabeli 4 przedstawiono skład i parametry zaczynu nr 2a z dodatkiem 0,1\% nanorurek węglowych. Rozlewność zaczynu 2a - po dodaniu nanorurek węglowych - zmalała do wartości $230 \mathrm{~mm}$. Zaczyn uzyskał $30 \mathrm{Bc}$ po czasie 3 godz. $18 \mathrm{~min}$, a $100 \mathrm{Bc}$ po 3 godz. $58 \mathrm{~min}$. W porównaniu do zaczynu bazowego czas gęstnienia skrócił się o około 90 min. Dodatek nanorurek węglowych obniżył filtrację zaczynu cementowego

Tabela 4. Zaczyn cementowy $\mathrm{nr} 2 \mathrm{a}$

Table 4. Cement slurry 2a

\begin{tabular}{|c|c|c|c|c|}
\hline \multicolumn{2}{|l|}{ Sklad zaczynu 2a } & \multicolumn{3}{|c|}{ Parametry zaczynu } \\
\hline Woda & $\mathrm{w} / \mathrm{c}=0,50$ & \multicolumn{2}{|l|}{ Gęstość $\left[\mathrm{g} / \mathrm{cm}^{3}\right]$} & 1,90 \\
\hline Dodatek upłynniający & $0,25 \%$ & \multicolumn{2}{|l|}{ Rozlewność [mm] } & 230 \\
\hline Dodatek antyfiltracyjny 1 & $0,9 \%$ & \multicolumn{2}{|l|}{ Odstój wody [\%] } & 0,0 \\
\hline Dodatek antyfiltracyjny 2 & $0,9 \%$ & \multicolumn{2}{|c|}{ Lepkość plastyczna $[\mathrm{mPa} \cdot \mathrm{s}]$} & 313,5 \\
\hline Dodatek odpieniający & $0,5 \%$ & \multicolumn{2}{|c|}{ Granica płynięcia YP [Pa] } & 14,2 \\
\hline $\mathrm{NaCl}$ (bwow) & $10,0 \%$ & \multirow{2}{*}{$\begin{array}{l}\text { Czas gęstnienia } \\
\left(80^{\circ} \mathrm{C}, 40 \mathrm{MPa}\right)\end{array}$} & $30 \mathrm{Bc}$ [h:min] & $3: 18$ \\
\hline Mikrocement & $5,0 \%$ & & $100 \mathrm{Bc}[\mathrm{h}: \mathrm{min}]$ & $3: 58$ \\
\hline MWCNTs & $0,1 \%$ & \multicolumn{2}{|c|}{ Filtracja $[\mathrm{ml} / 30 \mathrm{~min}]$} & 28 \\
\hline Cement G & $100,0 \%$ & & & \\
\hline \multicolumn{5}{|c|}{ Parametry mechaniczne $\left(80^{\circ} \mathrm{C}\right)$} \\
\hline & 2 dni & $7 \mathrm{dni}$ & 14 dni & $28 \mathrm{dni}$ \\
\hline Wytrzymałość na zginanie [MPa] & 9,0 & 9,3 & 9,6 & 10,0 \\
\hline Wytrzymałość na ściskanie [MPa] & 31,9 & 34,5 & 37,2 & 40,1 \\
\hline Przyczepność do rur [MPa] & 5,9 & 6,2 & 6,7 & 7,2 \\
\hline
\end{tabular}

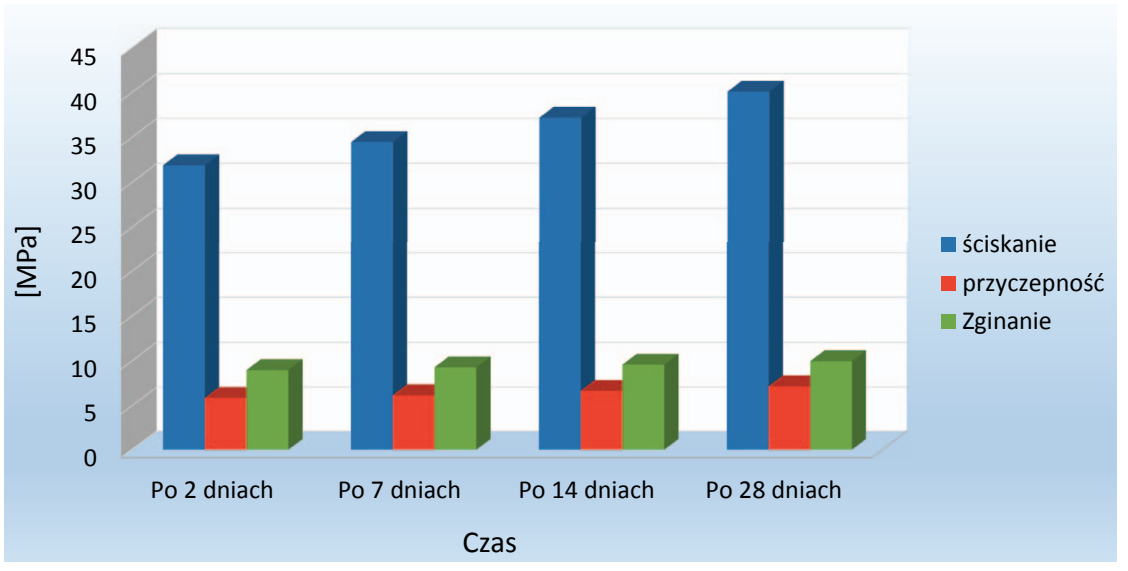

Rys. 4. Wytrzymałość mechaniczna kamienia cementowego $\mathrm{nr} 2 \mathrm{a}$

Fig. 4. Mechanical strength of sample $2 \mathrm{a}$ 
do wartości $28 \mathrm{~cm}^{3}$. Wytrzymałość na ściskanie w temperaturze $80^{\circ} \mathrm{C}$ po 28 dniach wzrosła do $40,1 \mathrm{MPa}$ i była wyższa o $2 \mathrm{MPa}$ w porównaniu do zaczynu nr 2. Dodatek nanorurek węglowych spowodował wzrost przyczepności do rur do wartości 7,2 $\mathrm{MPa}$ oraz wytrzymałości na zginanie do 10,0 MPa (rys. 4).

\section{Zaczyny cementowe dla temperatury $100^{\circ} \mathrm{C}$}

$\mathrm{W}$ tabeli 5 przedstawiono skład i parametry zaczynu bazowego nr 3, bez dodatku nanorurek węglowych. Zaczyn posiadał dodatek hematytu wynoszący $70,0 \%$ oraz dodatek mikrokrzemionki. Gęstość zaczynu miała wartość 2,25 g/ $\mathrm{cm}^{3}$. Zaczyn charakteryzował się odpowiednią reologią i zerowym odstojem wody. Uzyskał on konsystencję $30 \mathrm{Bc}$ po czasie 4 godz. $17 \mathrm{~min}$, a 100 Bc po 4 godz. 28 min. Filtracja zaczynu miała wartość $48 \mathrm{~cm}^{3}$. Rozlewność zaczynu wyniosła $250 \mathrm{~mm}$. Na rysunku 5 przedstawiono wykres wytrzymałości na ściskanie, zginanie i przyczepność do rur kamienia cementowego. Wytrzymałość kamienia cementowego na ściskanie po 28 dniach była równa 29,2 MPa, wytrzymałość na zginanie osiągnęła wartość 9,7 MPa, z kolei przyczepność do rur wyniosła 4,6 MPa.

Tabela 6 prezentuje skład i parametry zaczynu nr 3a, z dodatkiem $0,1 \%$ nanorurek węglowych. W porównaniu z zaczynem bazowym nr 3 zwiększono o 0,05\% ilość dodatku opóźniającego wiązanie. Rozlewność zaczynu zmalała do wartości $250 \mathrm{~mm}$. Zaczyn uzyskał 30 Bc po czasie 4 godz. $39 \mathrm{~min}$, a $100 \mathrm{Bc}$ po 4 godz. $51 \mathrm{~min}$. Dodatek nanorurek węglowych obniżył filtrację zaczynu cementowego do wartości $34 \mathrm{~cm}^{3}$. Wytrzymałość na ściskanie w temperaturze $100^{\circ} \mathrm{C}$ po 28 dniach wzrosła do $30,5 \mathrm{MPa}$ i była wyższa o około 1,5 MPa w porównaniu do zaczynu nr 3 (rys. 6).

\section{Zaczyny cementowe dla temperatury $130^{\circ} \mathrm{C}$}

W tabeli 7 przedstawiono skład i parametry zaczynu bazowego nr 4, bez dodatku nanorurek węglowych. Zaczyn

Tabela 5. Zaczyn cementowy nr 3

Table 5. Cement slurry 3

\begin{tabular}{|c|c|c|c|c|}
\hline \multicolumn{2}{|l|}{ Skład zaczynu 3} & \multicolumn{3}{|c|}{ Parametry zaczynu } \\
\hline Woda & $\mathrm{w} / \mathrm{c}=0,57$ & \multicolumn{2}{|l|}{ Gęstość $\left[\mathrm{g} / \mathrm{cm}^{3}\right]$} & 2,25 \\
\hline Dodatek upłynniający & $1,5 \%$ & \multicolumn{2}{|l|}{ Rozlewność [mm] } & 250 \\
\hline Dodatek odpieniający & $0,5 \%$ & \multicolumn{2}{|l|}{ Odstój wody [\%] } & 0,0 \\
\hline Dodatek opóźniający wiązanie & $0,3 \%$ & \multicolumn{2}{|c|}{ Lepkość plastyczna $[\mathrm{mPa} \cdot \mathrm{s}]$} & 327,0 \\
\hline Dodatek antyfiltracyjny 1 & $0,3 \%$ & \multicolumn{2}{|c|}{ Granica płynięcia YP [Pa] } & 5,3 \\
\hline Dodatek antyfiltracyjny 2 & $1,1 \%$ & \multirow{2}{*}{$\begin{array}{l}\text { Czas gęstnienia } \\
\left(100^{\circ} \mathrm{C}, 45 \mathrm{MPa}\right)\end{array}$} & $30 \mathrm{Bc}$ [h:min] & $4: 17$ \\
\hline $\mathrm{NaCl}$ (bwow) & $10,0 \%$ & & $100 \mathrm{Bc}$ [h:min] & $4: 28$ \\
\hline Mikrosilica & $20,0 \%$ & \multicolumn{2}{|c|}{ Filtracja $[\mathrm{ml} / 30 \mathrm{~min}]$} & 48 \\
\hline Hematyt & $70,0 \%$ & & & \\
\hline Cement G & $100,0 \%$ & & & \\
\hline \multicolumn{5}{|c|}{ Parametry mechaniczne $\left(100^{\circ} \mathrm{C}\right)$} \\
\hline & 2 dni & 7 dni & 14 dni & $28 \mathrm{dni}$ \\
\hline Wytrzymałość na zginanie [MPa] & 8,8 & 9,1 & 9,4 & 9,7 \\
\hline Wytrzymałość na ściskanie [MPa] & 23,0 & 25,1 & 27,8 & 29,2 \\
\hline Przyczepność do rur [MPa] & 3,5 & 3,9 & 4,3 & 4,6 \\
\hline
\end{tabular}

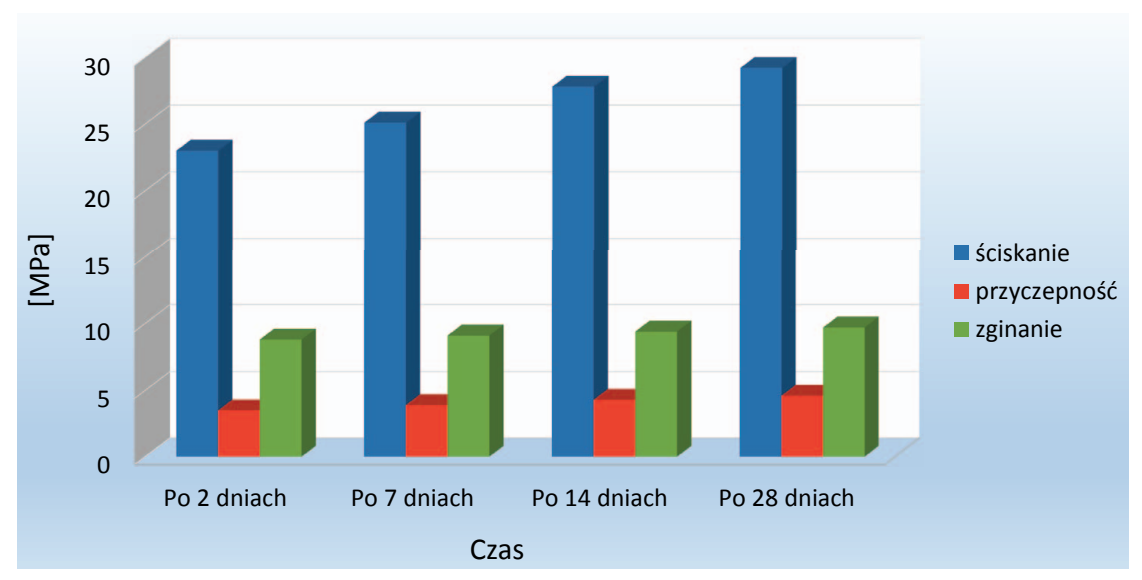

Rys. 5. Wytrzymałość mechaniczna kamienia cementowego $\mathrm{nr} 3$

Fig. 5. Mechanical strength of sample 3 
Tabela 6. Zaczyn cementowy nr 3a

Table 6. Cement slurry $3 \mathrm{a}$

\begin{tabular}{|c|c|c|c|c|}
\hline \multicolumn{2}{|c|}{ Skład zaczynu 3a } & \multicolumn{3}{|c|}{ Parametry zaczynu } \\
\hline Woda & $\mathrm{w} / \mathrm{c}=0,57$ & \multicolumn{2}{|l|}{ Gęstość $\left[\mathrm{g} / \mathrm{cm}^{3}\right]$} & 2,25 \\
\hline Dodatek upłynniający & $1,5 \%$ & \multicolumn{2}{|l|}{ Rozlewność [mm] } & 250 \\
\hline Dodatek odpieniający & $0,5 \%$ & \multicolumn{2}{|l|}{ Odstój wody [\%] } & 0,0 \\
\hline Dodatek opóźniający wiązanie & $0,35 \%$ & \multicolumn{2}{|c|}{ Lepkość plastyczna $[\mathrm{mPa} \cdot \mathrm{s}]$} & 328,5 \\
\hline Dodatek antyfiltracyjny 1 & $0,3 \%$ & \multicolumn{2}{|c|}{ Granica płynięcia YP [Pa] } & 4,6 \\
\hline Dodatek antyfiltracyjny 2 & $1,1 \%$ & \multirow{2}{*}{$\begin{array}{l}\text { Czas gęstnienia } \\
\left(100^{\circ} \mathrm{C}, 45 \mathrm{MPa}\right)\end{array}$} & $30 \mathrm{Bc}$ [h:min] & $4: 39$ \\
\hline $\mathrm{NaCl}$ (bwow) & $10,0 \%$ & & $100 \mathrm{Bc}[\mathrm{h}: \mathrm{min}]$ & $4: 51$ \\
\hline Mikrosilica & $20,0 \%$ & & 34 \\
\hline Hematyt & $70,0 \%$ & Filtracja $[\mathrm{ml} / 30 \mathrm{~min}]$ & & \\
\hline MWCNTs & $0,1 \%$ & & & \\
\hline Cement G & $100,0 \%$ & & & \\
\hline \multicolumn{5}{|c|}{ Parametry mechaniczne $\left(100^{\circ} \mathrm{C}\right)$} \\
\hline & 2 dni & 7 dni & 14 dni & $28 \mathrm{dni}$ \\
\hline Wytrzymałość na zginanie [MPa] & 8,8 & 9,2 & 9,5 & 10,0 \\
\hline Wytrzymałość na ściskanie [MPa] & 24,1 & 26,3 & 29,1 & 30,5 \\
\hline Przyczepność do rur [MPa] & 3,7 & 4,0 & 4,5 & 4,8 \\
\hline
\end{tabular}

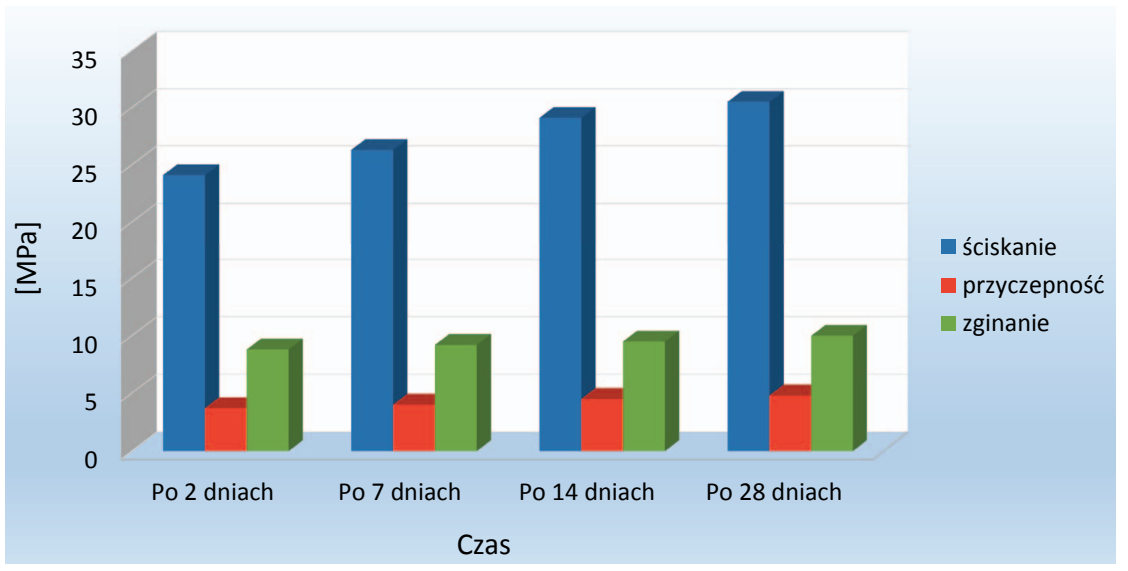

Rys. 6. Wytrzymałość mechaniczna kamienia cementowego $\mathrm{nr} 3 \mathrm{a}$

Fig. 6. Mechanical strength of sample 3a

Tabela 7. Zaczyn cementowy $\mathrm{nr} 4$

Table 7. Cement slurry 4

\begin{tabular}{|c|c|c|c|c|}
\hline \multicolumn{2}{|l|}{ Skład zaczynu 4} & \multicolumn{3}{|c|}{ Parametry zaczynu } \\
\hline Woda & $\mathrm{w} / \mathrm{c}=0,53$ & \multicolumn{2}{|l|}{ Gęstość $\left[\mathrm{g} / \mathrm{cm}^{3}\right]$} & 1,90 \\
\hline Dodatek upłynniający & $0,5 \%$ & \multicolumn{2}{|l|}{ Rozlewność [mm] } & 235 \\
\hline Dodatek odpieniający & $0,3 \%$ & \multicolumn{2}{|l|}{ Odstój wody [\%] } & 0,0 \\
\hline Dodatek opóźniający wiązanie & $0,3 \%$ & \multicolumn{2}{|c|}{ Lepkość plastyczna $[\mathrm{mPa} \cdot \mathrm{s}]$} & 232,5 \\
\hline Dodatek antyfiltracyjny 1 & $1,2 \%$ & \multicolumn{2}{|c|}{ Granica płynięcia YP [Pa] } & 51,6 \\
\hline Dodatek antyfiltracyjny 2 & $0,8 \%$ & \multirow{2}{*}{$\begin{array}{l}\text { Czas gęstnienia } \\
\left(130^{\circ} \mathrm{C}, 80 \mathrm{MPa}\right)\end{array}$} & $30 \mathrm{Bc}[\mathrm{h}: \mathrm{min}]$ & $4: 57$ \\
\hline Mikrosilica & $20,0 \%$ & & $100 \mathrm{Bc}[\mathrm{h}: \mathrm{min}]$ & $5: 49$ \\
\hline Cement G & $100,0 \%$ & \multicolumn{2}{|c|}{ Filtracja $[\mathrm{ml} / 30 \mathrm{~min}]$} & 34 \\
\hline \multicolumn{5}{|c|}{ Parametry mechaniczne $\left(130^{\circ} \mathrm{C}\right)$} \\
\hline & 2 dni & 7 dni & 14 dni & $28 \mathrm{dni}$ \\
\hline Wytrzymałość na zginanie [MPa] & 7,5 & 7,8 & 8,0 & 8,5 \\
\hline Wytrzymałość na ściskanie [MPa] & 18,3 & 20,2 & 23,1 & 26,3 \\
\hline Przyczepność do rur [MPa] & 3,5 & 3,8 & 4,0 & 4,3 \\
\hline
\end{tabular}


zawierał dodatek mikrokrzemionki. Gęstość zaczynu wyniosła $1,90 \mathrm{~g} / \mathrm{cm}^{3}$. Zaczyn charakteryzował się odpowiednią reologią i zerowym odstojem wody. Uzyskał on konsystencję $30 \mathrm{Bc}$ po czasie 4 godz. $57 \mathrm{~min}$, a $100 \mathrm{Bc}$ po 5 godz. 49 min. Filtracja zaczynu miała wartość $34 \mathrm{~cm}^{3}$. Rozlewność zaczynu wyniosła $235 \mathrm{~mm}$. Wytrzymałość kamienia cementowego na ściskanie po 28 dniach była równa $26,3 \mathrm{MPa}$. Wytrzymałość na zginanie po 28 dniach hydratacji osiągnęła wartość $8,5 \mathrm{MPa}$, a przyczepność do rur stalowych - 4,3 MPa (rys. 7).

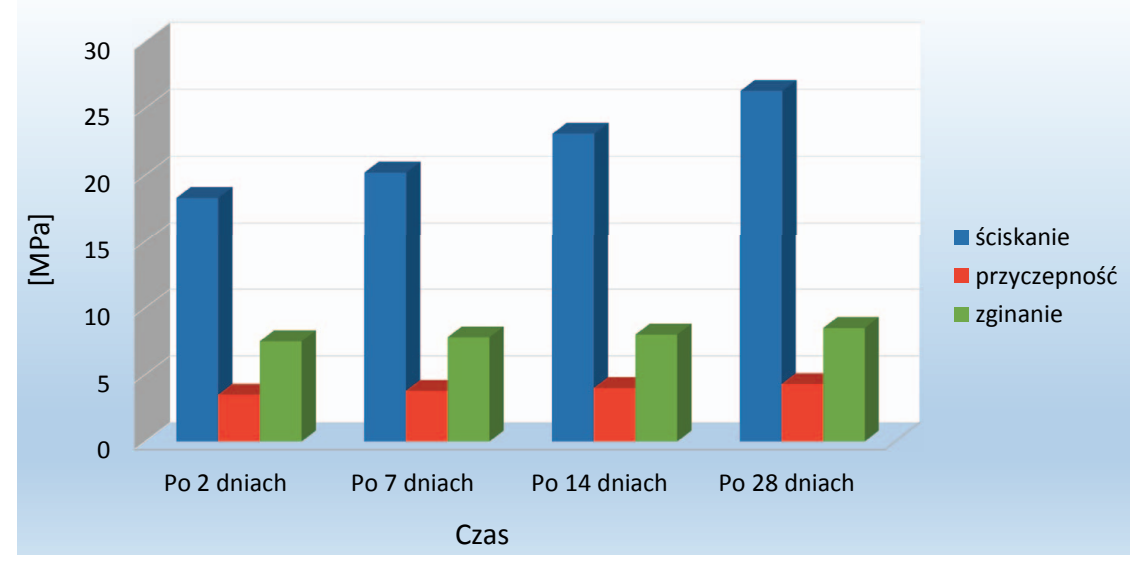

Rys. 7. Wytrzymałość mechaniczna kamienia cementowego $\mathrm{nr} 4$

Fig. 7. Mechanical strength of sample 4

Tabela 8. Zaczyn cementowy $\mathrm{nr} 4 \mathrm{a}$

Table 8. Cement slurry $4 a$

\begin{tabular}{|c|c|c|c|c|}
\hline \multicolumn{2}{|c|}{ Sklad zaczynu 4a } & \multicolumn{3}{|c|}{ Parametry zaczynu } \\
\hline Woda & $\mathrm{w} / \mathrm{c}=0,53$ & \multicolumn{2}{|l|}{ Gęstość $\left[\mathrm{g} / \mathrm{cm}^{3}\right]$} & 1,90 \\
\hline Dodatek upłynniający & $0,5 \%$ & \multicolumn{2}{|l|}{ Rozlewność [mm] } & 225 \\
\hline Dodatek odpieniający & $0,3 \%$ & \multicolumn{2}{|l|}{ Odstój wody [\%] } & 0,0 \\
\hline Dodatek opóźniający wiązanie & $0,3 \%$ & \multicolumn{2}{|c|}{ Lepkość plastyczna $[\mathrm{mPa} \cdot \mathrm{s}]$} & 235,5 \\
\hline Dodatek antyfiltracyjny 1 & $1,2 \%$ & \multicolumn{2}{|c|}{ Granica płynięcia YP [Pa] } & 52,6 \\
\hline Dodatek antyfiltracyjny 2 & $0,8 \%$ & \multirow{2}{*}{$\begin{array}{l}\text { Czas gęstnienia } \\
\left(130^{\circ} \mathrm{C}, 80 \mathrm{MPa}\right)\end{array}$} & $30 \mathrm{Bc}[\mathrm{h}: \min ]$ & $4: 21$ \\
\hline Mikrosilica & $20,0 \%$ & & $100 \mathrm{Bc}[\mathrm{h}: \mathrm{min}]$ & $5: 21$ \\
\hline Cement G & $100,0 \%$ & \multicolumn{2}{|c|}{ Filtracja $[\mathrm{ml} / 30 \mathrm{~min}]$} & 22 \\
\hline MWCNTs & $0,1 \%$ & & & \\
\hline \multicolumn{5}{|c|}{ Parametry mechaniczne $\left(130^{\circ} \mathrm{C}\right)$} \\
\hline & 2 dni & 7 dni & 14 dni & $28 \mathrm{dni}$ \\
\hline Wytrzymałość na zginanie [MPa] & 7,5 & 7,9 & 8,1 & 8,7 \\
\hline Wytrzymałość na ściskanie [MPa] & 19,0 & 20,9 & 24,2 & 28,7 \\
\hline Przyczepność do rur [MPa] & 3,6 & 4,0 & 4,2 & 4,5 \\
\hline
\end{tabular}

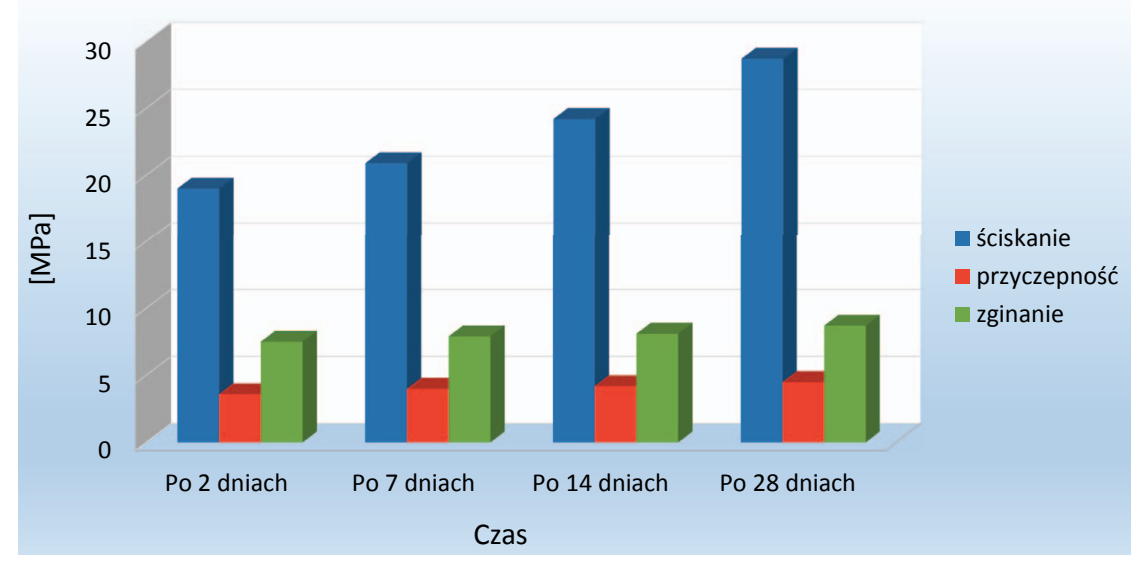

Rys. 8. Wytrzymałość mechaniczna kamienia cementowego $\mathrm{nr} 4 \mathrm{a}$

Fig. 8. Mechanical strength of sample $4 a$ 
Tabela 8 prezentuje skład i parametry zaczynu nr 4a, z dodatkiem 0,1\% nanorurek węglowych. Rozlewność zaczynu wyniosła $225 \mathrm{~mm}$. Zaczyn uzyskał konsystencję 30 Bc po czasie 4 godz. $21 \mathrm{~min}$, a $100 \mathrm{Bc}$ po 5 godz. $21 \mathrm{~min}$ i był to czas krótszy od czasu gęstnienia zaczynu bazowego nr 4 o około 25 min. Dodatek nanorurek węglowych obniżył filtrację zaczynu cementowego do wartości $22 \mathrm{~cm}^{3}$. Wytrzymałość na ściskanie w temperaturze $130^{\circ} \mathrm{C}$ po 28 dniach wzrosła do 28,7 MPa i była wyższa w porównaniu z zaczynem bazowym nr 4 o około $2 \mathrm{MPa}$ (rys. 8). Dodatek nanorurek węglowych spowodował wzrost przyczepności do rur oraz wytrzymałości na zginanie.

\section{Wnioski}

Po przeprowadzeniu szeregu badań laboratoryjnych można wysnuć następujące wnioski:

- Dodatek 0,1\% nanorurek węglowych spowodował zmianę parametrów reologicznych zaczynu oraz spadek rozlewności zaczynów cementowych.

- Można zaobserwować wzrost wytrzymałości mechanicznej kamienia cementowego po dodaniu nanocząsteczek do zaczynu. Największe wartości wytrzymałości na ściskanie uzyskano dla zaczynu nr 1a (44,3 MPa) oraz dla zaczynu nr 2a (40,1 MPa).

- W przypadku zaczynu cementowego 2a uzyskano bardzo wysoką wytrzymałość po 2 dniach hydratacji, wynoszącą 31,9 MPa, co byłoby bardzo trudne do osiągnięcia w przypadku zastosowania konwencjonalnego zaczynu cementowego.

- Po dodaniu nanorurek węglowych otrzymano wysokie wartości wytrzymałości kamienia cementowego na zginanie, dochodzące do 10,8 MPa (zaczyn nr 1a).

- Zaobserwowano zmniejszenie filtracji zaczynu w porównaniu z zaczynem bazowym.

Wyniki przeprowadzonych badań pozwalają zauważyć pozytywny wpływ dodatku nanorurek węglowych na wytrzymałość kamieni cementowych w warunkach HPHT. Tak zmodyfikowane kamienie charakteryzują się wysokimi wartościami wytrzymałości na ściskanie oraz wysokimi przyczepnościami do rur stalowych.

Przeprowadzone badania przyczyniły się do określenia wpływu nanorurek węglowych na parametry technologiczne zaczynów i kamieni cementowych stosowanych w wiertnictwie. Konieczne są dalsze badania w kierunku określenia wpływu nanorurek węglowych na mikrostrukturę kamienia cementowego. Niezbędne jest również kontynuowanie badań nad określeniem optymalnych ilości tych środków oraz doborem najbardziej kompatybilnych dodatków do zaczynów cementowych działających w sposób optymalny w połączeniu z nanocząsteczkami.

Artykuł powstał na podstawie pracy statutowej pt. Wpływ nanorurek węglowych na parametry technologiczne zaczynów i kamieni cementowych $w$ warunkach HPHT - praca INiG - PIB na zlecenie MNiSW; nr zlecenia: 0025/KW/2020, nr archiwalny: DK-4100-0013/2020.

\section{Literatura}

Al-Saud T.S., Bin Hussain M.A.A., Batyanovskii E.I., Zhdanok S.A., Krauklis A.V., Samtsou P.P., 2011. Influence of carbon nanomaterials on the properties of cement and concrete. Journal of Engineering Physics and Thermophysics, 84(3): 546-553. DOI: 10.1007/s10891-011-0503-y.

Campillo I., Dolado J.S., Porro A., 2004. High-performance nanostructured materials for construction. W: Bartos P.J.M. (ed.). Proceedings of 1st International Symposium on Nanotechnology in Construction. Cambridge, England.

Chaipanich A., Nochaiya T., Wongkeo W., Torkittikul P., 2010. Compressive strength and microstructure of carbon nanotubes fly ash cement composites. Materials Science and Engineering, 527(4-5): 1063-1067. DOI: 10.1016/j.msea.2009.09.039.

Collins F., Lambert J., Duan W.H., 2012. The influence of admixtures on the dispersion, workability, and strength of carbon nanotubeOPC paste mixtures. Cement and Concrete Composites, 34(2): 201-207. DOI: 10.1016/j.cemconcomp.2011.09.013.

Cwirzen A., Habermehl-Cwirzen K., Nasibulin A.G., Kaupinen E.I., Mudimela P.R., Penttala V., 2009. SEM/AFM studies of cementitious binder modified by MWCNT and nano-sized Fe needles. Materials Characterization, 60(7): 735-740. DOI: 10.1016/j. matchar.2008.11.001.

De La Roij R., Egyed C., Lips J.P., 2012. Nano-Engineered Oil Well Cement Improves Flexibility And Increases Compressive Strength: A Laboratory Study. Society of Petroleum Engineers. DOI: 10.2118/156501-MS.

De Paula J.N., Calixto J.M., Ladeira L.O., Ludvig P., Souza T.C.C., 2018. Tensile Strength of Oil-Well Cement Pastes Produced with Carbon Nanotubes Directly Synthesized on Clinker. The International Journal of Engineering and Science, 7(7): 57-62. DOI: 10.9790/1813-0707015762 .

De Paula J.N., Calixto J.M., Ladeira L.O., Ludvig P., Souza T.C.C., Rocha J.M., Vargas de Melo A.A., 2014. Mechanical and rheological behavior of oil-well cement slurries produced with clinker containing carbon nanotubes. Journal of Petroleum Science and Engineering, 122: 274-279. DOI: 10.1016/j.petrol.2014.07.020.

Dębińska E., 2014. Wpływ nanokrzemionki na parametry mechaniczne kamienia cementowego. Nafta-Gaz, 4: 229-235.

Dębińska E., 2015. Niekonwencjonalne zaczyny cementowe z dodatkiem nanokrzemionki. Nafta-Gaz, 5: 290-300.

Dębińska E., 2016. Wpływ nanotlenków glinu i cynku na parametry świeżego i stwardniałego zaczynu cementowego. Nafta-Gaz, 4: 251-261. DOI: 10.18668/NG.2016.04.04.

Dębińska E., Rzepka M., Kremieniewski M., 2016. Nanocząsteczki - nowa droga w kształtowaniu parametrów świeżych i stwardniałych zaczynów cementowych. Nafta-Gaz, 12: 1084-1091. DOI: 10.18668/NG.2016.12.11.

Dresselhaus M.S., Dresselhaus G., Eklund P.C., 1996. Science of Fullerenes and Carbon Nanotubes: Their Properties and Applications. Academic Press, San Diego, California.

El-Gamal S.M.A., Hashem F.S., Amin M.S., 2017. Influence of carbon 
nanotubes, nanosilica and nanometakaolin on some morphological-mechanical properties of oil well cement pastes subjected to elevated water curing temperature and regular room air curing temperature. Construction and Building Materials, 146: 531-546. DOI: 10.1016/j.conbuildmat.2017.04.124.

Ershadi V., Ebadi T., 2011. The Effect of Nanosilica on Cement Matrix Permeability in Oil Well to Decrease the Pollution of Receptive Environment. International Journal of Environmental Science and Development, 2(2): 128-132. DOI: 10.7763/IJESD.2011.V2.109.

Ghajari A., Gholinezhad J., Soltanian H., Mortazavi S.A., 2014. An improvement to physical properties of heavy-weight oil well cements using carbon nanotubes. Journal of Petroleum Science and Technology, 4(2): 10-19. DOI: 10.22078/jpst.2014.401.

Haddad A.N., de Morais J.F, 2014. Analysis by ultrasound of the behavior of carbon nanotubes on cementitious composites. Journal of Nanotechnology and Advance Materials, 2(2): 89-98. DOI: 10.12785/jnam/020206.

Horszczaruk E., Mijowska E., Cendrowski K., Mijowska S., Sikora P., 2013. Wpływ nanokrzemionki o zróżnicowanej morfologii na właściwości mechaniczne zapraw cementowych. Cement Wapno Beton, 1: 24-32.

Huang X., Qi Y., Boey F., Zhang H., 2012. Graphene based composites. Chemical Society Reviews, 41(2): 666-686. DOI: 10.1039/ c1cs15078b.

Kosta-Gdoutos M.S., Metaxa Z.S., Shah S.P., 2010. Multi-scale mechanical and fracture characteristics and early-age strain capacity of high performance carbon nanotube/cement nanocomposites. Cement and Concrete Composites, 32(2): 110-115. DOI: 10.1016/j.cemconcomp.2009.10.007.

Kuilla T., Bhadra S., Yao D., Kim N.H., Bose S., Lee J.H., 2010. Recent advances in graphene based polymer composites. Progress in Polymer Science, 35(11): 1350-1375. DOI: 10.1016/j. progpolymsci.2010.07.005.

Li G.Y., Wang P.M., Zhao X., 2005. Mechanical behavior and microstructure of cement composites incorporating surface-treated multi-walled carbon nanotubes. Carbon, 43(6): 1239-1245. DOI: 10.1016/j.carbon.2004.12.017.

Li G.Y., Wang P.M., Zhao X., 2007. Pressure-sensitive properties and microstructure of carbon nanotube reinforced cement composites. Cement and Concrete Composites, 29(5): 377-382. DOI: 10.1016/j.cemconcomp.2006.12.011.

Li H., Xiao H., Yuan J., Ou J., 2004. Microstructure of Cement Mortar with Nano-Particles. Composites Part B: Engineering, 35: 185-189. DOI: 10.1016/S1359-8368(03)00052-0.

Li X., Rafieepour S., Miska S.Z., Takach N.E., Ozbayoglu E., Tu M., Mata C., 2019. Carbon nanotubes reinforced lightweight cement testing under tri-axial loading conditions. Journal of Petroleum Science and Engineering, 174: 663-675. DOI: 10.1016/j. petrol.2018.11.077.

Li Z., Wang H., He S., Lu Y., Wang M., 2006. Investigations on the preparation and mechanical properties of the nano-alumina reinforced cement composite. Materials Letters, 60(3): 356-359. DOI: 10.1016/j.matlet.2005.08.061.

Luo J., Duan Z., Li H., 2009. The influence of surfactants on the processing of multi-walled carbon nanotubes in reinforced cement matrix composites. Physica Status Solidi (a), 206(12): 2783-2790. DOI: $10.1002 /$ pssa.200824310.

Musso S., Tulliani J.-M., Ferro G., Tagliaferro A., 2009. Influence of carbon nanotubes structure on the mechanical behavior of cement composites. Composites Science and Technology, 69(11-12): 1985-1990. DOI: 10.1016/j.compscitech.2009.05.002.
Nasibulin A.G., Koltsiva T., Nasibulin L.I., Anoshkin I.V., Semencha A., Tolochko O.V., Kauppinen E.I., 2013. A novel approach to composite preparation by direct synthesis of carbon nanomaterial on matrix or filler particles. Acta Materialia, 61(6): 1862-1871. DOI: 10.1016/j.actamat.2012.12.007.

Nazari A., Riahi S., 2011. $\mathrm{Al}_{2} \mathrm{O}_{3}$ nanoparticles in concrete and different curing media. Energy and Buildings, 43(6): 1480-1488. DOI: 10.1016/j.enbuild.2011.02.018.

Pandey P., Dahiya M., 2016. Carbon Nanotubes: Types, Methods of Preparation and Applications. International Journal of Pharmaceutical Science and Research, 1(4): 15-21.

Patil R., Deshpande A., 2012. Use of Nanomaterials in Cementing Applications. Society of Petroleum Engineers. DOI: 10.2118/155607-MS.

Rahman M.K., Khan W.A., Mahmoud M.A., Sarmah P., 2016a. MWCNT for Enhancing Mechanical and Thixotropic Properties of Cement for HPHT Applications. Offshore Technology Conference. DOI: $10.4043 / 26465-M S$.

Rahman M.K., Murtaza M., Al-Majed A.A., 2016b. Effect of Nanoclay on Mechanical and Rheological Properties of Oil Well Cement Slurry under HPHT Environment. International Petroleum Technology Conference. DOI: 10.2523/IPTC-18989-MS.

Wang B., Han Y., Liu S., 2013. Effect of highly dispersed carbon nanotubes on the flexural toughness of cement-based composites. Construction and Building Materials, 46: 8-12. DOI: 10.1016/j. conbuildmat.2013.04.014.

\section{Normy}

PN-EN ISO 10426-1:2009 Przemysł naftowy i gazowniczy - Cementy i materiały do cementowania otworów - Część 1: Specyfikacja.

PN-EN ISO 10426-2:2003 Przemysł naftowy i gazowniczy - Cementy i materiały do cementowania otworów wiertniczych - Część 2: Badania cementów wiertniczych.

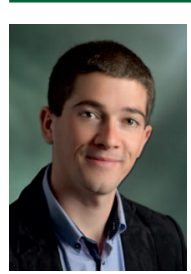

Mgr inż. Miłosz KĘDZIERSKI

Asystent w Zakładzie Technologii Wiercenia

Instytut Nafty i Gazu - Państwowy Instytut Badawczy ul. Lubicz 25 A

31-503 Kraków

E-mail: milosz.kedzierski@inig.pl

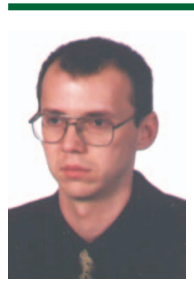

Dr inż. Marcin RZEPKA

Kierownik Laboratorium Zaczynów Uszczelniających w Zakładzie Technologii Wiercenia

Instytut Nafty i Gazu - Państwowy Instytut Badawczy ul. Lubicz 25 A

31-503 Kraków

E-mail: marcin.rzepka@inig.pl

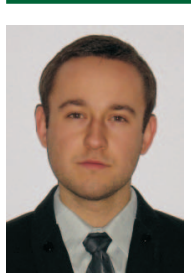

Dr inż. Marcin KREMIENIEWSKI

Adiunkt w Zakładzie Technologii Wiercenia Instytut Nafty i Gazu - Państwowy Instytut Badawczy ul. Lubicz $25 \mathrm{~A}$

31-503 Kraków

E-mail: marcin.kremieniewski@inig.pl 